\title{
Chlorella mirabilis as a potential species for biomass production in low-temperature environment
}

\author{
S. P. Shukla ${ }^{1,2}$, J. Kvíderová2,3 *, J. Tríska ${ }^{3,4}$ and J. Elster ${ }^{2,3 *}$ \\ ' Aquatic Environment Management Division, Central Institute of Fisheries Education, Mumbai, India \\ ${ }^{2}$ Centre for Phycology, Institute of Botany AS CR, Třeboň, Czech Republic \\ ${ }^{3}$ Faculty of Science, University of South Bohemia, České Budějovice, Czech Republic \\ ${ }^{4}$ Laboratory of Metabolomics and Isotopic Analyses, Global Change Research Centre AS CR, České Budějovice, Czech Republic
}

\section{Edited by:}

Elena Gonzalez-Toril, INTA-CSIC, Spain

Reviewed by:

Elena Gonzalez-Toril, INTA-CSIC, Spain

Lingling Wu, University of

Wisconsin-Madison, USA

\section{${ }^{*}$ Correspondence:}

J. Kvíderová, Institute of Botany AS

CR, Dukelská 135, 37982 Třeboň,

Czech Republic.

e-mail:kviderova@butbn.cas.cz;

J. Elster, Faculty of Science,

University of South Bohemia,

Branišovská 31, 37005 České

Budèjovice, Czech Republic.

e-mail: jelster@butbn.cas.cz
Successful adaptation/acclimatization to low temperatures in micro-algae is usually connected with production of specific biotechnologically important compounds. In this study, we evaluated the growth characteristics in a micro-scale mass cultivation of the Antarctic soil green alga Chlorella mirabilis under different nitrogen and carbon sources followed by analyses of fatty acid contents. The micro-scale mass cultivation was performed in stable (in-door) and variable (out-door) conditions during winter and/or early spring in the Czech Republic. In the in-door cultivation, the treatments for nitrogen and carbon sources determination included pure Z medium (control, Z), Z medium $+5 \%$ glycerol (ZG), $\mathrm{Z}$ medium $+5 \%$ glycerol $+50 \mu \mathrm{M} \mathrm{KNO}_{3}(\mathrm{ZGN}), \mathrm{Z}$ medium $+5 \%$ glycerol $+200 \mu \mathrm{M} \mathrm{NH} \mathrm{H}_{4} \mathrm{Cl}$ (ZGA), $Z$ medium $+5 \%$ glycerol $+1 \mathrm{mM} \mathrm{Na}_{2} \mathrm{CO}_{3}(\mathrm{ZNC}), \mathrm{Z}$ medium $+5 \%$ glycerol $+1 \mathrm{mM}$ $\mathrm{Na}_{2} \mathrm{CO}_{3}+200 \mu \mathrm{M} \mathrm{NH}{ }_{4} \mathrm{Cl}$ (ZGCA) and Z medium $+5 \%$ glycerol $+1 \mathrm{mM} \mathrm{Na}_{2} \mathrm{CO}_{3}+50 \mu \mathrm{M}$ $\mathrm{KNO}_{3}(\mathrm{ZGCN})$ and were performed at $15^{\circ} \mathrm{C}$ with an irradiance of $75 \mu \mathrm{mol} \mathrm{m} \mathrm{m}^{-2} \mathrm{~s}^{-1}$. During the out-door experiments, the night-day temperature ranged from -6.6 to $17.5^{\circ} \mathrm{C}$ (daily average $3.1 \pm 5.3^{\circ} \mathrm{C}$ ) and irradiance ranged from 0 to $2,300 \mu \mathrm{mol} \mathrm{m}^{-2} \mathrm{~s}^{-1}$ (daily average $1,500 \pm 1,090 \mu \mathrm{mol} \mathrm{m}^{-2} \mathrm{~s}^{-1}$ ). Only the Z, ZG, ZGN, and ZGC treatments were used in the out-door cultivation. In the in-door mass cultivation, all nitrogen and carbon sources additions increased the growth rate with the exception of ZGA. When individual sources were considered, only the effect of $5 \%$ glycerol addition was significant. On the other hand, the growth rate decreased in the ZG and ZGN treatments in the out-door experiment, probably due to carbon limitation. Fatty acid composition showed increased production of linoleic acid in the glycerol treatments. The studied strain of $C$. mirabilis is proposed to be a promising source of linoleic acid in low-temperature-mass cultivation biotechnology. This strain is a perspective model organism for biotechnology in low-temperature conditions.

Keywords: microalgae, growth rate, $\mathrm{N}$ and $\mathrm{C}$ manipulation, fatty acid content, low temperature

\section{INTRODUCTION}

Micro-algae are considered to be a promising alternative in aquaculture feed formulation due to their photoautotrophic mode of nutrition and their ability to grow in inorganic media under a wide range of environmental conditions (e.g., Bennemann et al., 1987). Two major advantages associated with the use of unicellular organisms including micro-algae are: (a) a well-defined protocol for industrial production under controlled and environmentally safe conditions (Sanchez et al., 1995) and (b) the inherent capability for manipulating (physiological and genetic) the strains to produce higher quantities of the desired compounds (e.g., polyunsaturated fatty acids, polyols, carotenoids, or phycocyanin (Tan and Johns, 1991; Day and Tsavalos, 1996).

Substantial information about the applications of micro-algae from various bio-geographic regions is available in the literature (Zhou et al., 1991; Langden and Onal, 1999; Harel et al., 2002, etc.). However, there is a scarcity of base-line data for the potentialities of micro-algae originating from various habitats in the polar regions. Cold-adapted, psychrophilic, or psychrotolerant, micro-algae have evolved a complex network of adaptation/acclimatization reactions to survive in low-temperature environments (Shukla et al., 1997a,b; Shukla and Kashyap, 2003; Elster and Benson, 2004; Pandey et al., 2004; Vonshak and Torzillo, 2004; Elster et al., 2008). Their successful survival is usually connected with production of specific biotechnologically important compounds like polyunsaturated fatty acids, polyols, and low-temperature enzymes. Especially poly-unsaturated fatty acids are of primary interest to the food industry and could be obtained from various micro-algae and cyanobacteria (Řezanka et al., 2008, 2009). Since these compounds are valuable in the food, cosmetics, and pharmacological industries, such biotechnology in low-temperature environments could be beneficial in areas with lower temperatures like temperate regions in winter/early spring conditions or the polar regions in summer.

So far, the majority of commercial mass cultivations were performed in tropical and subtropical zones due to growth requirements of commercially used slightly thermophilic and mesophilic strains like Spirulina, Dunaliella salina, or Haematococcus pluvialis 
(Borowitzka, 2005). In temperate areas, because of requirements for higher and more or less stable temperatures, and because of appropriate light conditions, out-door mass cultivations operate during summer months (May-September) only (Masojídek et al., 1999). The cultivation units do not operate during the rest of the year. Cultivation of cold-adapted strains in late winter or spring (February-May) could extend unit utilization for approximately 4 months, providing additional income. In polar regions, to the best of our knowledge, micro-algae and cyanobacteria mass cultivation technology has not been tested yet. Polar summer conditions offer continuous light and more/less stable temperature conditions which provide an additional advantage. The appropriate conditions for mass cultivation of low-temperature adapted micro-algae and cyanobacteria in polar areas could be proposed for three or at a maximum 4 months only.

Even though the cultivation scale-up of micro-algae in polar regions seem to be difficult due to the harsh climatic conditions, on the basis of introduced results the innovative development of micro-algae biotechnology in low-temperature environment is feasible. It is challenge for micro-algae research society to development photobioreactors for extreme polar regions environmental conditions. Such a technology could potentially help to develop local industry and at the same time provide a viable means of treating domestic wastewaters generated by local communities.

There are two plausible reasons for the limited number of reports on polar micro-algae biotechnological applications; logistical constraints in the collection of samples, and the tedious process of isolation and cultivation of unialgal and axenic strains. A prospective strain for low-temperature mass cultivation should be able to grow at near-zero temperatures $\left(0-5^{\circ} \mathrm{C}\right)$, tolerate temperatures up to $20^{\circ} \mathrm{C}$, have minimum requirements for nutrient additions and high primary production rates across a broad temperature range. The ecophysiological requirements for temperature and light of Chlorella-like species isolated from the Arctic or Antarctic could be suitable for out-door cultivation under varying conditions. Generally, polar micro-algae should be adapted to low nutrient conditions (Elster and Svoboda, 1995; Elster, 1996, 2002; Dickson, 2000; Elster et al., 2001; Elster and Benson, 2004; Kaštovská et al., 2005); such a lower nutrient demand can reduce the costs of mass cultivation. A nutrient requirement study confirmed the low nitrogen requirements in some Arctic and Antarctic strains, but also revealed serious carbon limitation during cultivation (Shukla et al., 2011).

The aim of this study was to evaluate the possibilities of microscale mass cultivation (growth rate) of an Antarctic soil green alga Chlorella mirabilis strain L10 in in-door and out-door conditions for production of poly-unsaturated fatty acids under different nutrient conditions. The period of out-door cultivation, performed in a temperate region - the Czech Republic, Central Europe, was selected as late winter or early spring (FebruaryApril) in order to mimic the temperature environments of the polar summer. The results of the study serve as base-line information for the optimization of biomass yield and its biotechnological composition in a polar strain of micro-algae under in-door and out-door conditions, and potentially also for out-door cultivation of micro-algae in polar environments.

\section{MATERIALS AND METHODS EXPERIMENTAL STRAIN}

The experimental strain Chlorella mirabilis Andreeva 1973 strain Lukešová 10/1997 (L10) was isolated from deglaciated soil on King George Island, South Shetland, maritime Antarctic (S $62^{\circ}$ $\left.10^{\prime} \mathrm{W} 58^{\circ} 30^{\prime}\right)$. The strain is kept in the Culture Collection of Autotrophic Organisms at the Institute of Botany AS $\mathrm{CR}$ in Třeboň, Czech Republic. The stock culture was kept at $12^{\circ} \mathrm{C}$ and $50 \mu \mathrm{mol} \mathrm{m}^{-2} \mathrm{~s}^{-1}$ of photosynthetically active radiation (PAR) in $\mathrm{Z}$ medium (Staub, 1961). The growth optimum and limits of the experimental strain were evaluated using cultivation in crossed gradients of temperature $\left(-4\right.$ to $\left.+24^{\circ} \mathrm{C}\right)$ and PAR (fluorescent tubes; $5-65 \mu \mathrm{mol} \mathrm{m}^{-2} \mathrm{~s}^{-1}$ ). The cultivation unit and procedures are described in Kvíderová and Lukavský (2001) and Kvíderová and Lukavský (2005). The minimum growth temperature of this strain is $4.5-10.1^{\circ} \mathrm{C}$ and the maximum $>20.5^{\circ} \mathrm{C}$. Optimum growth was observed in the range $10.1-20.5^{\circ} \mathrm{C}$. The minimum irradiance requirement is 12.3 $15.9 \mu \mathrm{mol} \mathrm{m}^{-2} \mathrm{~s}^{-1}$, maximum at $27.8 \mu \mathrm{mol} \mathrm{m}^{-2} \mathrm{~s}^{-1}$, with an optimal range of $15.9-21.5 \mu \mathrm{mol} \mathrm{m}^{-2} \mathrm{~s}^{-1}$. Tolerance to irradiances above $65 \mu \mathrm{mol} \mathrm{m}^{-2} \mathrm{~s}^{-1}$ remains unknown, since these values were not used during cultivation in crossed gradients.

\section{MINERAL MEDIA COMPOSITION}

Sterilized Z medium (21) with the desired concentrations of chemicals was added to each cultivation treatment. Addition of $5 \%(\mathrm{v} / \mathrm{v})$ glycerol was used: (a) to prevent freezing of the suspension in the out-door experiment, since sub-zero temperatures were expected and (b) as an organic C source. Glycerol, together with the electrically heated mattresses of the cultivation platform bottom (see description of the out-door cultivation unit below), kept the cultivation solution in a liquid state. The effect of different nitrogen sources was tested by addition of either $200 \mu \mathrm{M} \mathrm{NH} \mathrm{Cl}_{4}$ or $50 \mu \mathrm{M}$ $\mathrm{KNO}_{3}$. To test and prevent carbon limitation, $1 \mathrm{mM} \mathrm{Na}_{2} \mathrm{CO}_{3}$ was added. The combined effect of nitrogen and carbon additions was also evaluated (see detailed treatment descriptions and their abbreviations in Table 1). $\mathrm{pH}$ of the complete medium was adjusted to 7.5 by titration of $0.1 \mathrm{~N} \mathrm{HCl}$ and $\mathrm{NaOH}$. The $\mathrm{pH}$ of the medium was checked by a CPH51 laboratory pH-meter (Crytur, Czech Republic).

Nutrient treatments for the out-door conditions were selected according to the best growth parameters tested in the in-door experiments. Out-door cultivation conditions are summarized in Table 1.

\section{GROWTH RATE CALCULATION}

The inoculum sizes of an exponentially growing population of Chlorella mirabilis strain Lukešová L10 were added to each flask or well in order to obtain initial optical density values (absorbance) at $750 \mathrm{~nm}\left(A_{750}\right)$ of 0.05 . This $A_{750}$ value corresponds to the detection limit of the iEMS plate reader (LabSystems, Finland; see, Kvíderová, 2010 for initial cell density justification). The $A_{750}$ was measured once every 2 days during the in-door cultivation and once a day during the out-door cultivation. Six $200 \mu l$ sub-samples were poured into individual wells in a micro-plate (transparent, 96 wells, flat bottom) and the $A_{750}$ was measured using a plate reader. 
Table 1 | Nutrient treatments, their abbreviations and applications in in-door and out-door micro-scale mass cultivation experiments.

\begin{tabular}{llll}
\hline Treatment & Abbreviation & In-door & Out-door \\
\hline Z medium (control) & $\mathrm{Z}$ & $\checkmark$ & $\checkmark$ \\
$\mathrm{Z}$ medium $+5 \%(\mathrm{v} / \mathrm{v})$ glycerol & $\mathrm{ZG}$ & $\checkmark$ & $\checkmark$ \\
$\mathrm{Z}$ medium $+5 \%(\mathrm{v} / \mathrm{v})$ & $\mathrm{ZGA}$ & $\checkmark$ & \\
glycerol $+200 \mu \mathrm{M} \mathrm{NH}{ }_{4} \mathrm{Cl}$ & & & \\
$\mathrm{Z}$ medium $+5 \%(\mathrm{v} / \mathrm{v})$ & $\mathrm{ZGN}$ & $\checkmark$ & $\checkmark$ \\
glycerol $+50 \mu \mathrm{M} \mathrm{KNO} \mathrm{N}_{3}$ & & & \\
$\mathrm{Z}$ medium $+5 \%(\mathrm{v} / \mathrm{v})$ & $\mathrm{ZGC}$ & $\checkmark$ & $\checkmark$ \\
glycerol $+1 \mathrm{mM} \mathrm{Na}_{2} \mathrm{CO}_{3}$ & & & \\
$\mathrm{Z}$ medium $+5 \%(\mathrm{v} / \mathrm{v})$ & $\mathrm{ZGCA}$ & $\checkmark$ & \\
glycerol $+1 \mathrm{mM} \mathrm{Na} \mathrm{CO}_{3}+200 \mu \mathrm{M}$ & & & \\
$\mathrm{NH}_{4} \mathrm{Cl}$ & & & \\
$\mathrm{Z} \mathrm{medium}+5 \%(\mathrm{v} / \mathrm{v})$ & & \\
glycerol $+1 \mathrm{mM} \mathrm{Na}_{2} \mathrm{CO}_{3}+50 \mu \mathrm{M}$ & & \\
$\mathrm{KNO}_{3}$ & &
\end{tabular}

The values of the $A_{750}$ were converted to number of cells $N$ (cells $\mathrm{ml}^{-1}$ ) according to a conversion equation. The conversion equation parameters were estimated according to the method described in Kvíderová and Lukavský (2003) and Kvíderová (2010). The culture was grown in similar conditions as those in the experiments. The density of the undiluted culture was set to $A_{750}=\sim 1.5-2.0$ and was diluted by factors of 0.5 , $0.3,0.1,0.05,0.03,0.01,0.005,0.003,0.001,0.0005,0.0003$, and 0.0001 . Distilled water served as a blank. Cell number was counted using Bürker's chamber. The conversion equation for Chlorella mirabilis L10 and the above specified equipment (plate reader, micro-plate, suspension volume) is as follows $\left(r^{2}=0.995\right)$ :

$$
N\left[\text { cells ml }{ }^{-1}\right]=\frac{A_{750}-0.04}{3.54 \times 10^{-8}}
$$

where $N$ is the number of cells per milliliter and $A_{750}$ the value of optical density (absorbance) at $750 \mathrm{~nm}$.

Two types of growth rates were calculated. The partial growth rate $\left(\mu_{\text {part }} ;\right.$ day $\left.^{-1}\right)$ was calculated as

$$
\mu_{\text {part }}\left[\mathrm{d}^{-1}\right]=\frac{\ln N_{t+\mathrm{SI}}-\ln N_{t}}{\mathrm{SI}}
$$

where $\mu_{\text {part }}$ is the partial growth rate, $N_{t}$ is the cell count per ml during the first $A_{750}$ measurement, $N_{t+S I}$ is the cell count in the second $A_{750}$ measurement after SI, and SI is sampling interval in days, i.e., 2 for the in-door experiment and 1 for the out-door experiment. The growth rate during the whole experiment ( $\mu$, day $^{-1}$ ) was calculated as the slope of the linear regression of the dependency of $\ln N$ on time.

\section{IN-DOOR MICRO-SCALE MASS CULTIVATION EXPERIMENT}

The in-door mass cultivation experiment was performed in a closed cultivation unit (Labio, Czech Republic). The cultivation apparatus consisted of a 2501 insulated chamber with outer dimensions of $1,350 \times 750 \mathrm{~mm}$ and $1,120 \mathrm{~mm}$ depth. Refrigerating $(150 \mathrm{~W})$ and heating $(150 \mathrm{~W})$ units and a ventilator were installed in the bottom part of the box. A temperature range of 0 up to $30^{\circ} \mathrm{C}$ could be regulated. Above the chamber bottom, a linear shaker plate of size $800 \mathrm{~mm} \times 410 \mathrm{~mm} \times 20 \mathrm{~mm}$ with a speed of $0-1 / 2$ oscillations per second was installed. A cover made of double thermal insulation glass closed the upper part of the chamber. The chamber was illuminated by two to five fluorescent tubes positioned above the glass cover.

During the experiment, PAR and temperature in the chamber were $75 \mu \mathrm{mol} \mathrm{m}^{-2} \mathrm{~s}^{-1}$ and $15^{\circ} \mathrm{C}$, respectively. A lower irradiance corresponding to the growth optimum could not be set due to the technical parameters of the unit. The irradiance of $75 \mu \mathrm{mol} \mathrm{m}{ }^{-2} \mathrm{~s}^{-1}$ corresponds to the minimum number of fluorescent tubes which can ensure homogeneous irradiance inside the cultivation chamber. Seven 3-1 Erlenmeyer flasks were installed in the box and each flask was filled with 21 of $\mathrm{Z}$ medium with the desired concentrations of chemicals (see Table 1 for treatment descriptions). The cultures were shaken by a built-in linear shaker in the cultivation chamber. The speed of the shaking rate was kept at a maximum of a $1 / 2$ oscillation per second in order to prevent cell damage. A small aquarium pump pumped fresh air into the box in order to prevent carbon limitation. The in-door experiment lasted 8 days. The $A_{750}$ measurements were performed every second day.

\section{OUT-DOOR MICRO-SCALE MASS CULTIVATION EXPERIMENT}

The out-door cultivation experiment was performed in an outdoor cultivation table (Labio, Czech Republic, Figure 1, see (Elster et al., 2001) for unit technical details). The cultivation unit consisted of a solid platform supporting a shallow polycarbonate pan with dimensions of $1,333 \mathrm{~mm} \times 750 \mathrm{~mm}$ and $70 \mathrm{~mm}$ deep. The pan was made with a double bottom. In the drawer-like cavity, four electrically heated mattresses $(800 \mathrm{~W}$ each) were installed. The pan area was divided into four rectangular chambers of equal size using a Perspex sheet. The pan was gently shaken using a motor, worm screws and belt pulley. To each rectangular well on the cultivation unit, 21 of $\mathrm{Z}$ medium with the desired concentrations of chemicals was added (see Table $\mathbf{1}$ for treatment descriptions). The platform was covered with a thin, transparent polythene sheet to prevent loss of the medium due to evaporation and stabilize the temperature of the culture.

The platform was installed in the backyard of the Institute of Botany in Trebon (Figure 1) and three 6-day independent cultivations were performed from March 13 to April 7, 2005. The experiment performed from March 19 to 25, 2005 showed the highest harvest and was selected for a detailed evaluation. Irradiance, temperature, and pH (Kombibox WTE, Weilheim, CB 570) of the cultivation treatments together with regulation of the heating mattresses were performed in the morning and afternoon. In addition, weather conditions (air temperature including min. and max. values, irradiance, air pressure, humidity, and precipitation) were monitored at $15 \mathrm{~min}$ intervals by an automatic weather station (AWS; ENVI s.r.o). The station is installed on the roof of a building about $200 \mathrm{~m}$ from the place where the experiments were performed. 

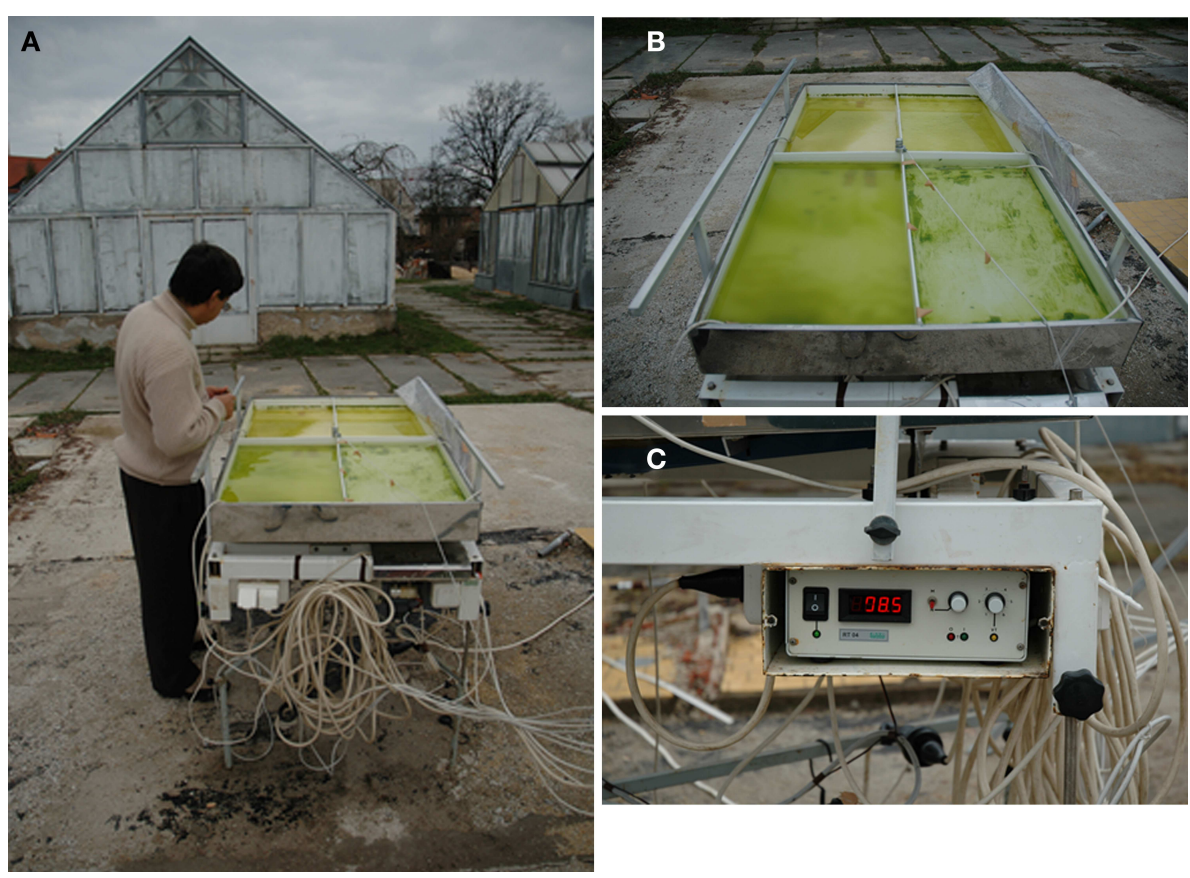

FIGURE 1 |The out-door micro-scale mass cultivation experiment. (A) The cultivation unit (Labio, Czech Republic), (B) detailed view of the cultivation well with micro-algal culture, (C) detailed view of the thermoregulation control unit.

\section{FATTY ACID ANALYSIS}

At the end of both the in-door/out-door cultivation experiments, algal biomass was centrifuged and lyophilized. About $25 \mathrm{mg}$ of the lyophilized micro-algae biomass were mixed in a $7 \mathrm{ml}$ vial with $5 \mathrm{ml}$ of a chloroform:methanol $(2: 1)$ mixture and kept at $50^{\circ} \mathrm{C}$ for $2 \mathrm{~h}$ with occasional shaking. The extract was separated and the biomass extracted once again by the same procedure. The joint extracts were filtered and evaporated to dryness by nitrogen blowing. About $0.5 \mathrm{ml}$ of boron trifluoride in methanol was added to the remainder and the reaction mixture was kept for several minutes at $50^{\circ} \mathrm{C}$. After the reaction was completed, $0.5 \mathrm{ml}$ of water was added and the reaction mixture was extracted three times with hexane. Joint extracts were filtered through a short column filled with anhydrous sodium sulfate, concentrated down to $100 \mu \mathrm{l}$ by nitrogen flow and $1 \mu \mathrm{l}$ of the hexane extract was injected into a GC-MS (Finnigan GCQ instrument; column Zebron ZB-5, Phenomenex, USA, $30 \mathrm{~m} \times 0.25 \mathrm{~mm} \times 0.25 \mu \mathrm{m}$; temperature program: initial temperature $60^{\circ} \mathrm{C}$, followed by a step-wise increase of $20^{\circ} \mathrm{C} \mathrm{min}-1$ to $180^{\circ} \mathrm{C}$, then another step-wise increase of $2^{\circ} \mathrm{C} \mathrm{min}{ }^{-1}$ to $275^{\circ} \mathrm{C}$; temperature of the transfer line $275^{\circ} \mathrm{C}$, ion source $200^{\circ} \mathrm{C}$; linear velocity of the carrier gas (helium) $40 \mathrm{~cm} \mathrm{~s}^{-1}$; full scan spectra in the range of relative mass $\mathrm{m} / \mathrm{z}$ 50-450).

The acids were measured as methylesters arising from the transesterification reaction using boron trifluoride in methanol. The qualitative analyses of fatty acids methyl esters were performed using external Bacterial Acid Methyl Ester (BAME) Standard Mix (Supelco, Sigma-Aldrich, Czech Republic). Quantification of the methylesters was performed by normalization; the minor peaks which were not present in the BAME mixture were not evaluated.
The repeated injection of the mixture of methylesters revealed R.S.D. for individual peaks up to $5 \%$ as a maximum.

\section{STATISTICS}

Statistical analyses were performed using Statistica 10 (StatSoft, USA). Descriptive statistics were used to characterize the weather conditions during the out-door cultivation. The effect of individual treatments on growth rate was evaluated by $t$-test. When individual addition effects were evaluated, the Honest Significant Differences (HSD) test for unequal $n$ was used. Correlation analysis evaluated the relationship between the meteorological data obtained from the AWS and the microclimate data measured in the cultivation platform. Correlation analysis was also used to evaluate the effect of individual environmental variables on growth rates in control and manipulated treatments. The results were considered significant for $p<0.05$.

\section{RESULTS}

\section{IN-DOOR MICRO-SCALE MASS CULTIVATION EXPERIMENT}

The $\mu_{\text {part }}$ during the in-door cultivation was relatively low, ranging from -0.02 to $0.18 \mathrm{day}^{-1}$ in the control and from 0.09 to 0.28 day $^{-1}$ in the nutrient treatments and varied during the cultivation (Table 2). The drop in the partial growth rates from Day 4 to Day 6 was caused by technical problems, since it occurred almost in all cultures.

Even if the whole cultivation duration was considered, the $\mu$ of the control and various nutrient treatments were low and did not exceed 0.25 day $^{-1}$ (Table 2, Figure 2). The $\mu$ ranged from 0.06 to 0.17 day $^{-1}$ and from 0.16 to 0.28 day $^{-1}$ in the control and nutrient treatments, respectively. 
Table $2 \mid \mu_{\text {part }}$ and $\mu$ (day ${ }^{-1}$; mean $\pm S D, n=6$ ) of Chlorella mirabilis in various compositions of growth medium (see Table 1 for growth media explanations) under in-door conditions (irradiance of $75 \mu \mathrm{mol} \mathrm{m}^{-2} \mathrm{~s}^{-1}$ and temperature of $15^{\circ} \mathrm{C}$ ).

\begin{tabular}{|c|c|c|c|c|c|c|c|}
\hline & \multicolumn{7}{|c|}{ Growth medium } \\
\hline & $\mathbf{Z}$ & ZG & ZGA & ZGN & ZGC & ZGCA & ZGCN \\
\hline$\mu_{\text {part 2-4 }}$ & $0.12 \pm 0.05^{a}$ & $0.18 \pm 0.04^{b c}$ & $0.18 \pm 0.06^{a}$ & $0.23 \pm 0.03^{\mathrm{a}}$ & $0.27 \pm 0.02^{\mathrm{ab}}$ & $0.18 \pm 0.04^{\mathrm{ab}}$ & $0.17 \pm 0.08^{a}$ \\
\hline$\mu_{\text {part 4-6 }}$ & $-0.02 \pm 0.08^{b}$ & $0.11 \pm 0.05^{c}$ & $0.08 \pm 0.02^{b}$ & $0.22 \pm 0.04^{a}$ & $0.16 \pm 0.03^{a}$ & $0.09 \pm 0.08^{b}$ & $0.16 \pm 0.08^{a}$ \\
\hline$\mu_{\text {part 6-7 }}$ & $0.18 \pm 0.04^{a}$ & $0.22 \pm 0.03^{\mathrm{ab}}$ & $0.25 \pm 0.04^{a}$ & $0.24 \pm 0.04^{a}$ & $0.31 \pm 0.16^{b}$ & $0.23 \pm 0.07^{a}$ & $0.23 \pm 0.02^{a}$ \\
\hline
\end{tabular}

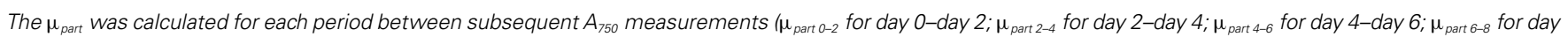

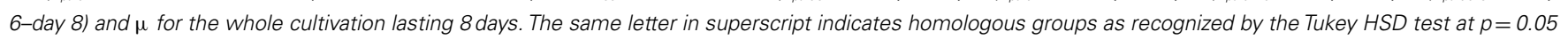
( $n=6$ in each group).

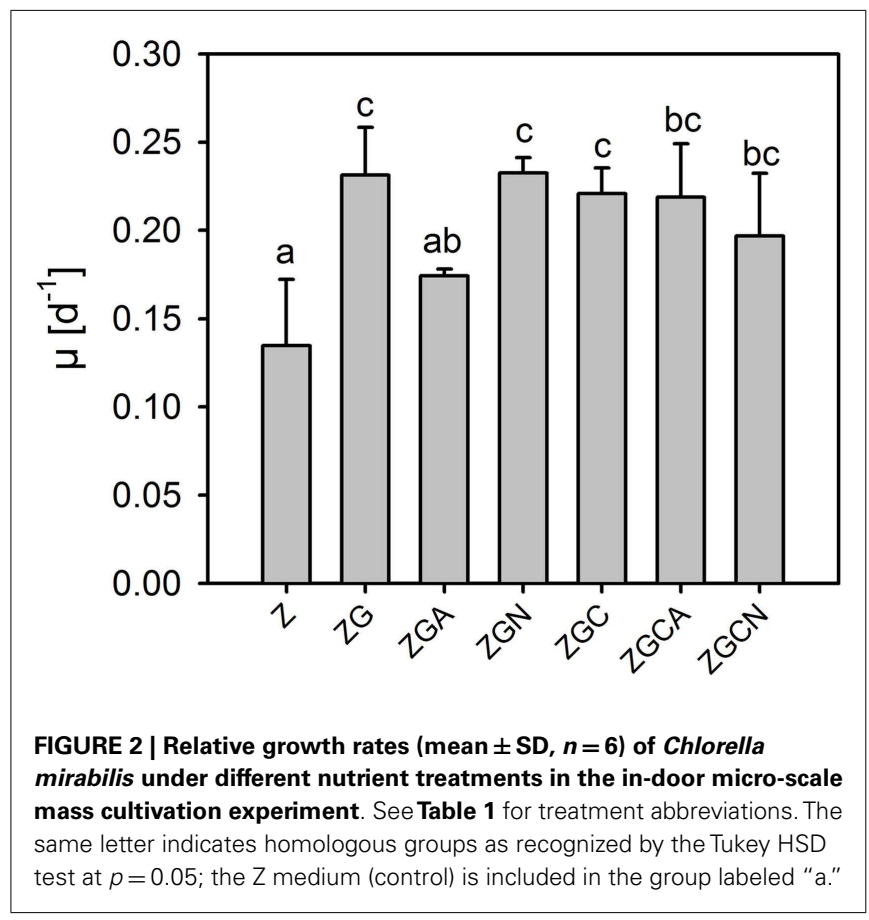

Relative growth rates were significantly greater in all nutrient treatments ( $t$-test, $n=6$ in each treatment, $p<0.049$ in all cases; Figure 2). The highest growth stimulations were $72 \pm 20 \%$ and $73 \pm 6 \%$ greater compared to the control in the ZG and ZGN treatments, respectively. The minimum increase in growth rate compared to the control was $29 \pm 3 \%$ in the ZGA treatment, indicating possible worse ammonium utilization (Figure 3). When the individual nutrient addition effects on the growth rate were considered, only glycerol increased the growth significantly (HSD for non-equal $n, p<0.001)$.

\section{OUT-DOOR MICRO-SCALE MASS CULTIVATION EXPERIMENT Weather and microclimate conditions}

The weather conditions during the out-door micro-scale mass cultivation (March 19-25, 2005) experiment were relatively stable with several minor precipitation events (Table 3, Figure 4).

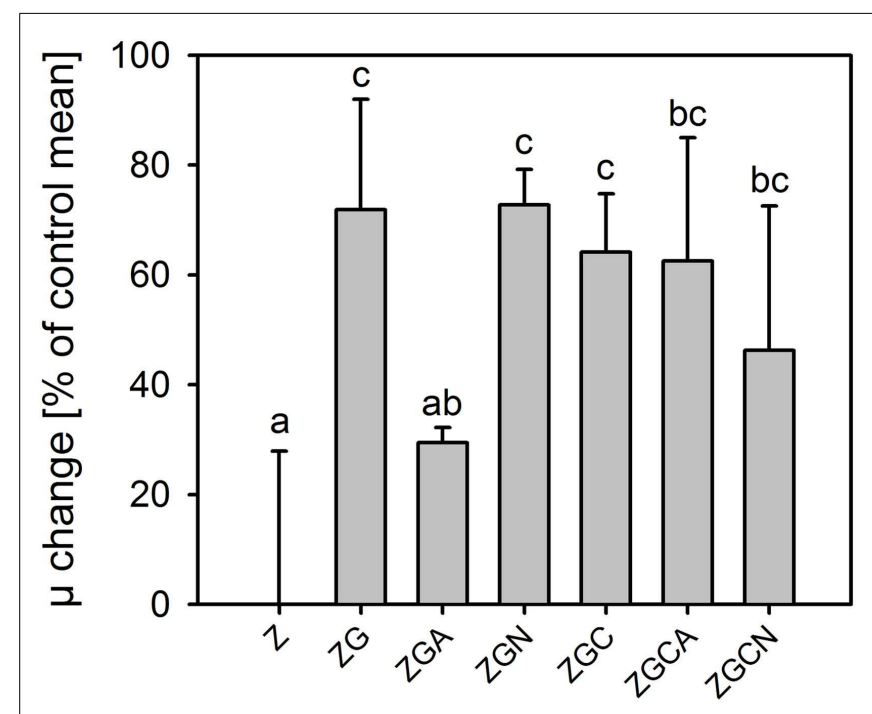

FIGURE 3 | Change in relative growth rates (mean $\pm S D, n=6$ ) of Chlorella mirabilis under different nutrient treatments in the in-door micro-scale mass cultivation experiment (see Table 1 for treatment abbreviations). The values were normalized to control mean (100\%). The zero line corresponds to $100 \%$ of the control. The same letter indicates homologous groups as recognized by the Tukey HSD test at $p=0.05$; the Z medium (control) is included in the group labeled "a."

The mean air temperature during the cultivation was $3.1 \pm 5.3$ (mean $\pm \mathrm{SD}, n=573$ ). The lowest air temperature was $-6.6^{\circ} \mathrm{C}$ while the maximum was $17.5^{\circ} \mathrm{C}$. Mean air pressure was $968 \pm 2 \mathrm{hPa}$ (mean $\pm \mathrm{SD}, n=573$ ) with a minimum of $963 \mathrm{hPa}$ and maximum of $973 \mathrm{hPa}$. Mean global irradiance was $329 \pm 238 \mathrm{~W} \mathrm{~m}^{-2}$ (mean $\pm \mathrm{SD}, n=293$ ) and reached even $711 \mathrm{~W} \mathrm{~m}^{-2}$. Mean relative air humidity was $71 \pm 20 \%($ mean $\pm \mathrm{SD}, n=573)$. The minimum relative air humidity was only $23 \%$ while the maximum rose to $98 \%$ during precipitation events. Seven precipitation events were recorded during the cultivation; however these precipitations were small, not exceeding $0.2 \mathrm{~mm}$. The weather data for each day of the out-door experiment are summarized in Table 3 and these data were used for further evaluation of environmental conditions on Chlorella mirabilis primary productivity. 


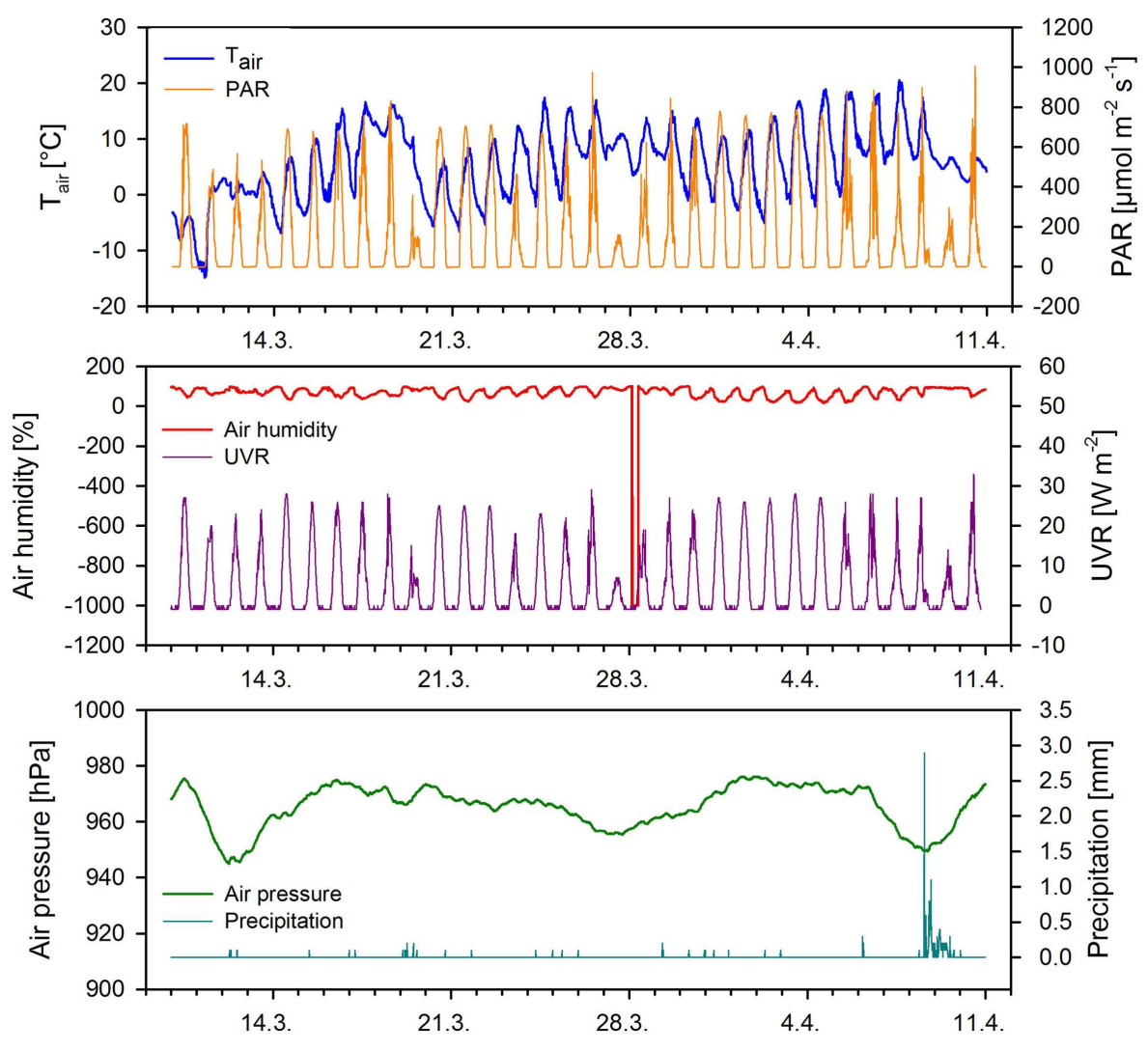

FIGURE 4 | Meteorological conditions during the out-door cultivation measured at 15-min intervals. Abbreviations: $T_{\text {air }}$, air temperature; PAR, photosynthetically active radiation; UVR, ultraviolet radiation.

The temperature and PAR in the cultivation unit differed a little from the AWS data (Table 4). The increased temperature in the cultivation unit was probably caused by it being covered by the polyethylene sheet resulting thus in a greenhouse effect. However, strong positive correlations were found between PAR irradiance in the cultivation unit and the AWS global radiation data $(n=17, r=0.917, t=8.93, p<0.001)$ as well as between the temperature in the cultivation unit and the AWS air temperature $(n=17, r=0.668, t=3.48, p=0.003)$, so the meteorological data could serve as a proxy data for microclimate conditions, with specific respect to the variation during cultivation.

\section{Algal primary production}

The $\mu_{\text {part }}$ varied every day; the growth rate ranged from -0.05 to 0.89 day $^{-1}$ and from -0.17 to 0.56 day $^{-1}$ in the control and nutrient manipulated treatments, respectively (Table 5). The high variability of $\mu_{\text {part }}$ was probably caused by weather conditions as indicated by decreased $\mu_{\text {part }}$ in all cultures at the same time. However, no statistically significant correlations were found between the growth rates of the control and/or the nutrient manipulation treatments and environmental variables (Table 6). A longer cultivation and dataloggers positioned inside the cultivation unit should reveal the response time of the culture to condition changes.
Several freezing periods were recorded during the out-door cultivation (Figure 4) that could affect the growth rate of the cultures. The cultures were frozen during the first three nights of the experiment. Microscopic examination of the cells after thawing of the cultures revealed destruction of about $30 \%$ of the cells after every bout of freezing. The culture in normal composition $\mathrm{Z}$ medium exhibited complete freezing whenever the temperature dropped below $-8^{\circ} \mathrm{C}$. The cultures in ZG and ZGC remained in a semifrozen state while $\mathrm{ZGN}$ remained in a liquid phase down to $-15^{\circ} \mathrm{C}$.

Means in the out-door experiment were higher than those in the in-door experiment for the control as well as every nutrient manipulated treatments ( $t$-test, $n=6$ in each treatment, $p<0.049$ in all cases, Tables 2 and 5; Figures 2 and 5). The $\mu$ of the control ranged from 0.41 to $0.61 \mathrm{day}^{-1}$, which is about four times higher than in the in-door experiment. The growth rates of the nutrient manipulated treatments ranged from 0.21 to 0.48 day $^{-1}$, about twice that in the in-door cultivation. The increased growth rates in the out-door cultivation could be caused by several factors:

(a) increased temperature, especially during the light phases,

(b) higher amount of received light energy $\left(1,382 \mathrm{~W} \mathrm{~m}^{-2}\right.$ during in-door experiment vs. $2,578-21,984 \mathrm{~W} \mathrm{~m}^{-2}$ during the outdoor experiment per day; data from in-door cultivation were recalculated according to formulas of Thimijan and Heins (1983) and 
Table 3 | Summarized weather conditions during the out-door cultivation experiment (March 19-25, 2005).

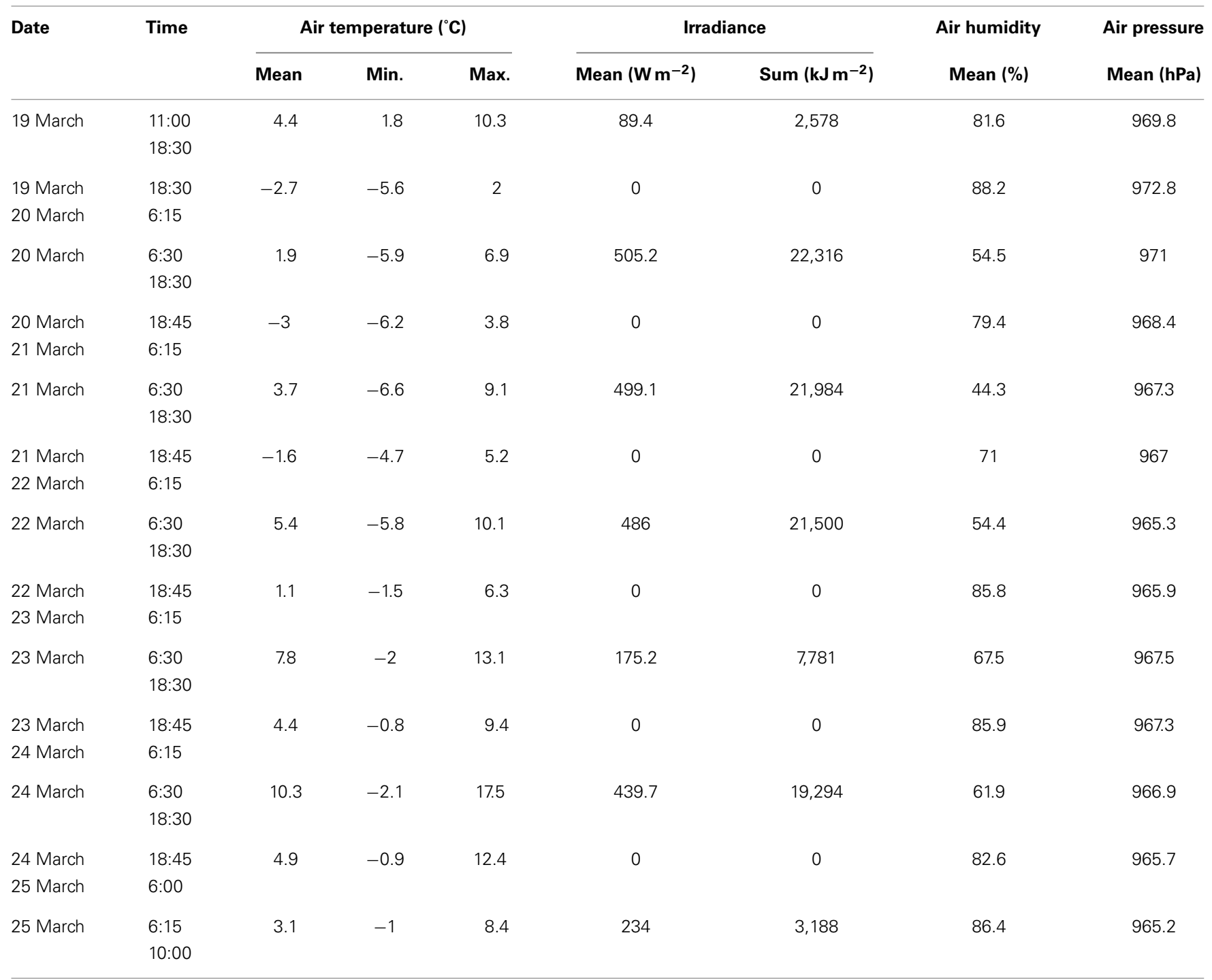

Presence and/or absence of sun irradiation delimit the time of day and night period for all measured parameters (mean, maximal and minimal air temperature, mean and sum of irradiance, mean air humidity and mean air pressure). For daylight periods, the mean values and sum of irradiance are shown.

(c) different air-liquid interface area affecting $\mathrm{CO}_{2}$ diffusion into the medium due to different types of cultivation vessels.

Contrary to the in-door cultivation, nutrient addition decreased the growth rate ( $t$-test, $n=6$ in each treatment, $p<0.002$; Figure 5). The most profound growth inhibition, by $42 \pm 8 \%$ compared to the control, was observed in the ZG treatment (Figure 6). Surprisingly, glycerol reduced the growth rate significantly (HSD for non-equal $n, p=0.026$, Figure 6). Effects of the other nutrient additions were not significant.

\section{FATTY ACIDS COMPOSITION}

The fatty acid analyses revealed increased production of linoleic acid in glycerol treatments. The fatty acid composition was similar in both experiments for individual treatments; however it differed among the treatments (Table 7). Oleic acid 18:1 (n-9) was the most abundant fatty acid found in the biomass of Chlorella mirabilis cultivated in the in-door experiment. This fatty acid can be found in all lipids of animal and plant origin. The trans-isomer of oleic acid (elaidic acid) is rarely found and also in this case it comprised only ca. $5 \%$ of the oleic acid content. Linoleic acid 18:2 (n-6) is an essential fatty acid in animal diets, because it is necessary for growth, reproduction and healthy development. It is the precursor of a family of other fatty acids. Its content in the biomass was about $11 \%$ of that of the oleic acid. There were some saturated acids in the biomass, e.g., palmitic acid 16:0 and myristic acid 14:0. When glycerol was added to the medium, the content of linoleic acid increased to $51 \%$ of the oleic acid content. The addition of $50 \mu \mathrm{M}$ $\mathrm{KNO}_{3}$ had no effect regarding production of unsaturated fatty acids. On the contrary, the content of saturated palmitic acid increased. 
Table 4 | Microclimate conditions (temperature and PAR) during the out-door experiment (March 19-25, 2005).

\begin{tabular}{|c|c|c|c|c|c|c|c|c|}
\hline & Date & Time & \multicolumn{5}{|c|}{ Temperature ( $\left.{ }^{\circ} \mathrm{C}\right)$} & $\begin{array}{l}\text { PAR } \\
\left(\mu \mathrm{mol} \mathrm{m}^{-2} \mathrm{~s}^{-1}\right)\end{array}$ \\
\hline & & $17: 00$ & 8.1 & 7.8 & 7.5 & 7.4 & $7.7 \pm 0.3$ & 75 \\
\hline Day 1 & 20 March & $8: 30$ & 8.2 & 7.9 & 6.8 & 6.6 & $7.4 \pm 0.8$ & 269 \\
\hline \multirow[t]{3}{*}{ Day 2} & 21 March & $8: 30$ & 8.5 & 8.1 & 7.1 & 7.2 & $7.7 \pm 0.7$ & 242 \\
\hline & & $14: 15$ & 27.6 & 28.1 & 25.6 & 27.2 & $27.1 \pm 1.1$ & 1,004 \\
\hline & & $16: 15$ & 21.2 & 21.4 & 22.7 & 22 & $21.8 \pm 0.7$ & 446 \\
\hline Day 3 & 22 March & $8: 45$ & 6.5 & 6.4 & 5.7 & 5.7 & $6.1 \pm 0.4$ & 202 \\
\hline Day 4 & & $14: 00$ & 23.2 & 23.2 & 23.1 & 23.1 & $23.2 \pm 0.1$ & 233 \\
\hline \multirow[t]{3}{*}{ Day 5} & 24 March & $10: 00$ & 20.9 & 20.5 & 20.4 & 19.9 & $20.4 \pm 0.4$ & 763 \\
\hline & & $14: 00$ & 33.1 & 32.8 & 34.4 & 33.4 & $33.4 \pm 0.7$ & 815 \\
\hline & & $17: 00$ & 18.2 & 18.6 & 17.9 & 18.4 & $18.3 \pm 0.3$ & 211 \\
\hline Day 6 & 25 March & $9: 40$ & 14.7 & 15.1 & 14.7 & 15.5 & $15.0 \pm 0.4$ & 688 \\
\hline
\end{tabular}

Temperature was measured in each treatment (see Table 1 for growth media abbreviation explanations) and mean \pm SD were calculated. Photosynthetically active radiation (PAR) was measured on the surface of the polythene cover.

\section{DISCUSSION}

Manipulation of culture conditions to enhance growth and production of useful compounds is one of the pre-requisites in microalgal biotechnology (Dunstan et al., 1994). There are numerous reports about the enhancement of growth and biomass yield by altering $\mathrm{pH}$, aeration rate, irradiance, temperature, cell concentration, and nitrogen and carbon sources in the medium (Cohen et al., 1988; Borowitzka, 1997) in strains of tropical, subtropical, and temperate origins. There is substantial data in the literature to support the fact that biomass yield of a few strains of micro-algae can be significantly increased by subjecting the cultures to mixotrophic growth conditions (Samejima and Myers, 1958). However, information is still scarce about polar strains of micro-algae with respect to culture conditions to enhance growth and production of useful compounds.

Our in-door cultivation experiments indicated that the Antarctic soil strain of Chlorella mirabilis shows an affinity toward mixotrophy. This was evident from the faster growth rate in the presence of $5 \%$ glycerol as compared to purely photoautotrophic cultures. These observations are in agreement with earlier reports for Chlorella sorokiniana (Lee and Low, 1992), Spirulina platensis (Chen and Zhang, 1997) and the diatom Phaeodactylum tricornutum (Cerón Garcí et al., 2000).

Results of the in-door experiment also suggest that our soil strain of Chlorella mirabilis has developed the ability to utilize organic compounds in general, because of the fact that the Antarctic soil environment contains a wide spectrum of diluted organic substances and also polar summer light conditions are
Table 5 | $\mu_{\text {part }}$ and $\mu$ (day ${ }^{-1}$; mean $\pm S D, n=6$ ) of Chlorella mirabilis during the out-door experiment (March 19-25, 2005) in control and nutrient manipulation treatments (see Table 1 for growth media abbreviation explanations).

\begin{tabular}{lrrrr}
\hline & \multicolumn{4}{c}{ Growth medium } \\
\cline { 2 - 5 } & $\mathbf{Z}$ & \multicolumn{2}{c}{ ZG } & \multicolumn{2}{c}{ ZGN } & \multicolumn{1}{c}{ ZGC } \\
\hline$\mu_{\text {part 0-1 }}$ & $0.48 \pm 0.24^{\mathrm{a}}$ & $0.56 \pm 0.18^{\mathrm{a}}$ & $0.36 \pm 0.14^{\mathrm{a}}$ & $0.51 \pm 0.09^{\mathrm{a}}$ \\
$\mu_{\text {part 1-2 }}$ & $-0.05 \pm 0.19^{\mathrm{b}}$ & $-0.17 \pm 0.08^{\mathrm{b}}$ & $-0.12 \pm 0.11^{\mathrm{b}}$ & $-0.03 \pm 0.13^{\mathrm{b}}$ \\
$\mu_{\text {part 2-3 }}$ & $0.32 \pm 0.12^{\mathrm{ac}}$ & $0.45 \pm 0.09^{\mathrm{a}}$ & $0.46 \pm 0.13^{\mathrm{a}}$ & $0.37 \pm 0.09^{\mathrm{a}}$ \\
$\mu_{\text {part 3-4 }}$ & $-0.01 \pm 0.13^{\mathrm{b}}$ & $0.00 \pm 0.10^{\mathrm{bc}}$ & $-0.09 \pm 0.07^{\mathrm{b}}$ & $-0.07 \pm 0.11^{\mathrm{b}}$ \\
$\mu_{\text {part 4-5 }}$ & $0.06 \pm 0.12^{\mathrm{bc}}$ & $0.12 \pm 0.12^{\mathrm{c}}$ & $0.33 \pm 0.08^{\mathrm{a}}$ & $0.36 \pm 0.11^{\mathrm{a}}$ \\
$\mu_{\text {part 5-6 }}$ & $0.89 \pm 0.22^{\mathrm{d}}$ & $0.44 \pm 0.04^{\mathrm{a}}$ & $0.46 \pm 0.05^{\mathrm{a}}$ & $0.52 \pm 0.06^{\mathrm{a}}$ \\
$\mu$ & $0.47 \pm 0.07$ & $0.28 \pm 0.04$ & $0.39 \pm 0.02$ & $0.44 \pm 0.03$
\end{tabular}

The $\mu_{\text {part }}$ was calculated for each period between subsequent $A_{750}$ measurements ( $\mu_{\text {part 0-1 }}$ for day 0-day $1 ; \mu_{\text {part 1-2 }}$ for day 1 -day $2 ; \mu_{\text {part 2-3 }}$ for day $2-$ day $3 ; \mu_{\text {part 3-4 }}$ for day 3-day 4; $\mu_{\text {part 4-5 }}$ for day 4-day 5; $\mu_{\text {part 5-6 }}$ for day 5-day 6$)$ and $\mu$ for the whole cultivation lasting 8 days. The same letter in superscript indicates homologous groups as recognized by the Tukey HSD test at $p=0.05$ ( $n=6$ in each group).

very variable. The Antarctic habitat, with a gradual accumulation of organic matter (due to slower mineralization processes), seems to be another logical explanation for the evolution of mixotrophy in polar soil micro-algae.

As has been shown in various reports, the lack of inorganic carbon and nitrogen often limits primary production in 
Table 6 | Correlations between environmental conditions measured by AWS and/or in the out-door unit, and $\mu_{\text {part }}$ of control and nutrient manipulated treatments in the out-door experiment.

\begin{tabular}{|c|c|c|c|c|}
\hline & $\mu_{Z}$ & $\mu_{Z G}$ & $\mu_{Z G N}$ & $\mu_{\mathrm{ZGC}}$ \\
\hline AWS $T_{m n} D$ & $\begin{array}{l}0.6091 \\
p=0.199\end{array}$ & $\begin{array}{l}0.3226 \\
p=0.533\end{array}$ & $\begin{array}{l}0.5082 \\
p=0.303\end{array}$ & $\begin{array}{l}0.5221 \\
p=0.288\end{array}$ \\
\hline AWS $T_{\min } \mathrm{D}$ & $\begin{array}{l}0.5000 \\
p=0.313\end{array}$ & $\begin{array}{l}0.5648 \\
p=0.243\end{array}$ & $\begin{array}{l}0.4683 \\
p=0.349\end{array}$ & $\begin{array}{l}0.6841 \\
p=0.134\end{array}$ \\
\hline AWS $T_{\max } D$ & $\begin{array}{l}0.7309 \\
p=0.099\end{array}$ & $\begin{array}{l}0.4245 \\
p=0.401\end{array}$ & $\begin{array}{l}0.5842 \\
p=0.223\end{array}$ & $\begin{array}{l}0.6141 \\
p=0.195\end{array}$ \\
\hline AWS $/ \mathrm{mn}$ & $\begin{array}{l}-0.1366 \\
p=0.796\end{array}$ & $\begin{array}{l}-0.4041 \\
p=0.427\end{array}$ & $\begin{array}{l}-0.3859 \\
p=0.450\end{array}$ & $\begin{array}{l}-0.5554 \\
p=0.253\end{array}$ \\
\hline AWS / sum & $\begin{array}{l}-0.1546 \\
p=0.770\end{array}$ & $\begin{array}{l}-0.4259 \\
p=0.400\end{array}$ & $\begin{array}{l}-0.3880 \\
p=0.447\end{array}$ & $\begin{array}{l}-0.5617 \\
p=0.246\end{array}$ \\
\hline AWS RH D & $\begin{array}{l}0.2887 \\
p=0.579\end{array}$ & $\begin{array}{l}0.3580 \\
p=0.486\end{array}$ & $\begin{array}{l}0.2404 \\
p=0.646\end{array}$ & $\begin{array}{l}0.4831 \\
p=0.332\end{array}$ \\
\hline AWS AP D & $\begin{array}{l}-0.1122 \\
p=0.832\end{array}$ & $\begin{array}{l}-0.1018 \\
p=0.848\end{array}$ & $\begin{array}{l}-0.1461 \\
p=0.782\end{array}$ & $\begin{array}{l}0.0177 \\
p=0.974\end{array}$ \\
\hline AWS $T_{m n} N$ & $\begin{array}{l}0.3239 \\
p=0.531\end{array}$ & $\begin{array}{l}0.0378 \\
p=0.943\end{array}$ & $\begin{array}{l}0.3214 \\
p=0.534\end{array}$ & $\begin{array}{l}0.2884 \\
p=0.579\end{array}$ \\
\hline AWS $T_{\min } N$ & $\begin{array}{l}0.1814 \\
p=0.731\end{array}$ & $\begin{array}{l}-0.0320 \\
p=0.952\end{array}$ & $\begin{array}{l}0.1813 \\
p=0.731\end{array}$ & $\begin{array}{l}0.1227 \\
p=0.817\end{array}$ \\
\hline AWS $T_{\max } \mathrm{N}$ & $\begin{array}{l}0.4250 \\
p=0.401\end{array}$ & $\begin{array}{l}0.0401 \\
p=0.940\end{array}$ & $\begin{array}{l}0.3428 \\
p=0.506\end{array}$ & $\begin{array}{l}0.2829 \\
p=0.587\end{array}$ \\
\hline AWS RH N & $\begin{array}{l}0.0073 \\
p=0.989\end{array}$ & $\begin{array}{l}-0.0546 \\
p=0.918\end{array}$ & $\begin{array}{l}-0.1784 \\
p=0.735\end{array}$ & $\begin{array}{l}0.0373 \\
p=0.944\end{array}$ \\
\hline AWS AP N & $\begin{array}{l}0.0378 \\
p=0.943\end{array}$ & $\begin{array}{l}0.3418 \\
p=0.507\end{array}$ & $\begin{array}{l}0.1002 \\
p=0.850\end{array}$ & $\begin{array}{l}0.2902 \\
p=0.577\end{array}$ \\
\hline Micro $T_{\mathrm{mn}}$ & $\begin{array}{l}0.3149 \\
p=0.543\end{array}$ & $\begin{array}{l}0-0.0399 \\
p=0.940\end{array}$ & $\begin{array}{l}0.3116 \\
p=0.548\end{array}$ & $\begin{array}{l}0.1658 \\
p=0.754\end{array}$ \\
\hline Micro PARmn & $\begin{array}{l}0.2335 \\
p=0.656\end{array}$ & $\begin{array}{l}-0.1034 \\
p=0.845\end{array}$ & $\begin{array}{l}0.0468 \\
p=0.930\end{array}$ & $\begin{array}{l}-0.1315 \\
p=0.804\end{array}$ \\
\hline
\end{tabular}

$A P$, air pressure; $A W S$, data measured by AWS; $D$, day time (sunrise to sunset); Imn, mean irradiance; $I_{\text {sum }}$, sum or received irradiance; Micro, data measures in the outdoor cultivation unit; $\mu$, growth rate, lower index indicates treatment (see Table 1 for treatment abbreviations); $N$, night time (sunset to sunrise); $P A R_{m n}$, mean PAR; $R H$, air humidity; $T_{\max }$, maximum temperature; $T_{\min }$, minimum temperature; $T_{\operatorname{mn}}$ mean temperature.

polar terrestrial and freshwater habitats (Henry and Svoboda, 1986; Davey and Rothery, 1992; Liengen and Olsen, 1997; Elster and Komárek, 2003; Walker et al., 2008). Our in-door cultivation experiment showed a positive response under additions of nitrogen and inorganic carbon.

Our analyses have proven that organic carbon (glycerol) is probably the key parameter influencing the growth rate of the Antarctic strain of Chlorella mirabilis. Growth rate responses to the addition of inorganic carbon and nitrogen were negligible

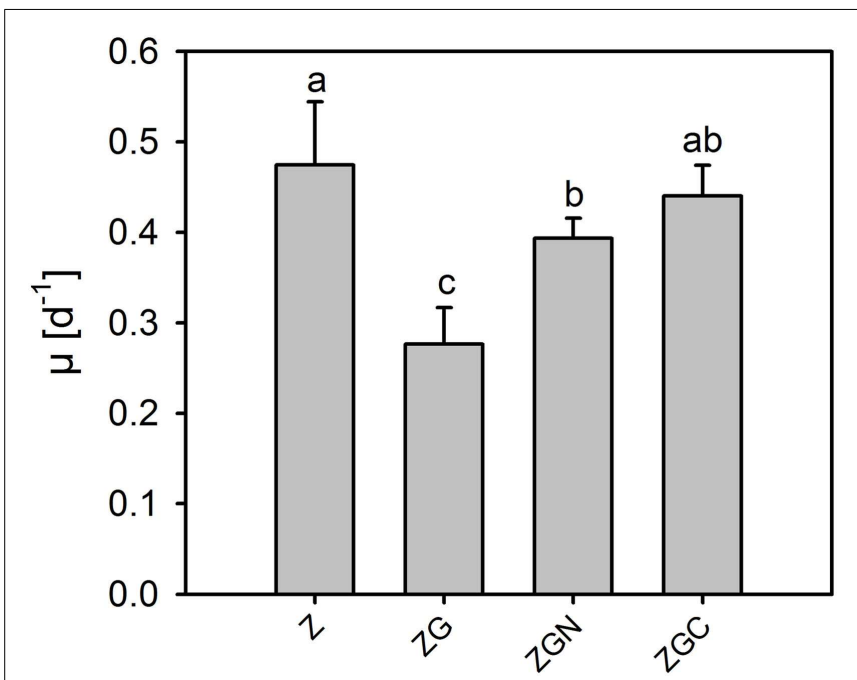

FIGURE 5 | Relative growth rates of Chlorella mirabilis under different nutrient treatments in the out-door micro-scale mass cultivation experiment. See Table 1 for treatment abbreviations (mean $\pm S D, n=6$ ). The same letter indicates homologous groups as recognized by the Tukey HSD test at $p=0.05$; the $Z$ medium (control) is included in the group labeled "a."

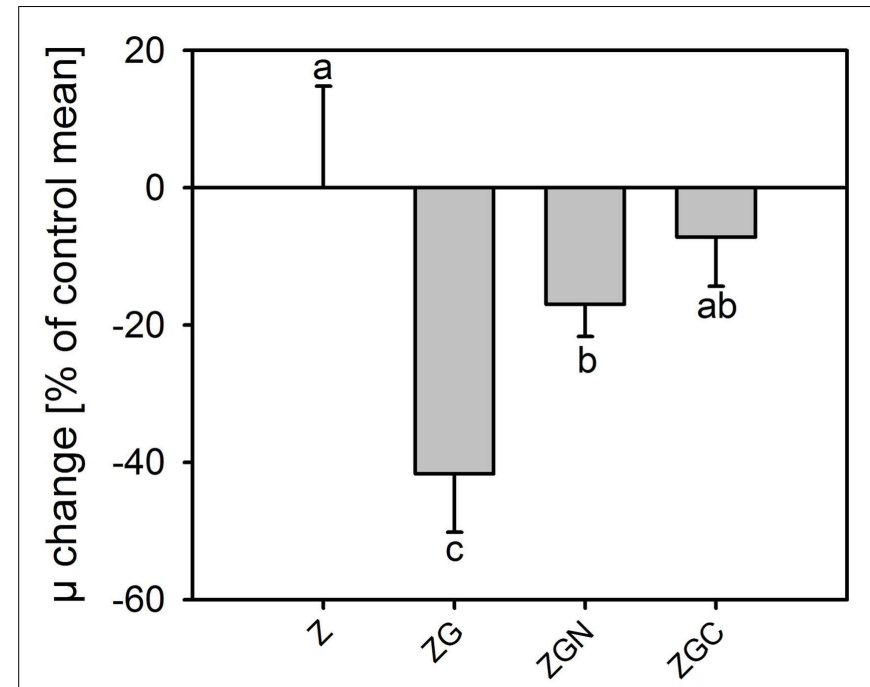

FIGURE 6 | Change in relative growth rates of Chlorella mirabilis under different nutrient treatments in the out-door micro-scale mass cultivation experiment. The values were normalized to the control mean (100\%). The zero line corresponds to $100 \%$ of the control. See Table 1 for treatment abbreviations (mean $\pm S D, n=6$ ). The same letter indicates homologous groups as recognized by the Tukey HSD test at $p=0.05$; the $Z$ medium (control) is included in the group labeled "a."

or negative and could be omitted in low-temperature mass cultivation of this strain. However, growth rate responses to the addition of organic or inorganic carbon and nitrogen are strainspecific. In our previous study (Shukla et al., 2011), it was shown that, for a majority of polar Chlorella-like strains, the addition of inorganic nitrogen (in both $\mathrm{N}-\mathrm{NO}_{3}$ and $\mathrm{N}-\mathrm{NH}_{4}$ forms) rather 
Table 7 | Fatty acid composition in the in-door and out-door cultivations for different treatments.

\begin{tabular}{|c|c|c|c|c|c|c|}
\hline \multirow[t]{2}{*}{ Sample } & \multicolumn{6}{|c|}{ Fatty acids composition (\%) } \\
\hline & $\begin{array}{l}\text { Myristic acid } \\
14: 0\end{array}$ & $\begin{array}{l}\text { Palmitic acid } \\
16: 0\end{array}$ & $\begin{array}{l}\text { Linoleic acid } \\
18: 2(n-6)\end{array}$ & $\begin{array}{l}\text { Oleic acid } \\
18: 1(n-9)\end{array}$ & $\begin{array}{l}\text { Elaidic acid } \\
18: 1(n-9)\end{array}$ & Unidentified \\
\hline \multicolumn{7}{|c|}{ IN-DOOR EXPERIMENTS } \\
\hline Z & 1.70 & 7.83 & 7.70 & 70.44 & 1.97 & 10.36 \\
\hline ZG & 0.37 & 16.00 & 22.60 & 40.31 & 1.62 & 19.10 \\
\hline ZGN & 1.49 & 23.46 & 15.13 & 49.97 & 2.83 & 7.12 \\
\hline \multicolumn{7}{|c|}{ OUT-DOOR EXPERIMENTS } \\
\hline Z & 0.87 & 10.72 & 16.86 & 49.87 & 0.83 & 20.85 \\
\hline ZG & 1.55 & 27.03 & 9.98 & 49.62 & 3.65 & 8.17 \\
\hline ZGN & 1.44 & 23.84 & 10.20 & 43.28 & 10.37 & 10.87 \\
\hline
\end{tabular}

See Table 1 for treatment abbreviations.

inhibited the growth rate indicating thus possible nitrogen oversaturation. The positive effect of carbon addition observed by Shukla et al. (2011) could indicate carbon limitation during the experiment.

The growth rates in the out-door cultivation were generally higher than for the in-door conditions. There are several explanations for these findings:

(a) increased temperature of up to $23^{\circ} \mathrm{C}$ in the out-door cultivation stimulated micro-algal growth. Under natural conditions of Trebon, Czech Republic, Central Europe (during late winter and/or early spring 2005), the growth of the soil Antarctic strain Chlorella mirabilis dramatically increased during the period when light and temperature fluctuated between 250 and $1,000 \mu \mathrm{mol} \mathrm{m}^{-2} \mathrm{~s}^{-1}$ and $8-23^{\circ} \mathrm{C}$. On the contrary, growth was arrested during and after the intermittent freezing of the cultures after a sudden drop in the atmospheric temperature. Microscopic examination of the cells after thawing of the cultures revealed destruction of about $30 \%$ of the cells after every bout of freezing. The culture in normal composition $\mathrm{Z}$ medium exhibited complete freezing whenever the temperature dropped below $-8^{\circ} \mathrm{C}$. The cultures in $\mathrm{ZG}$ and $Z G C$ remained in a semi-frozen state while $Z G N$ remained in a liquid phase down to $-15^{\circ} \mathrm{C}$. This observation suggests that modification of the growth medium ( $\mathrm{Z}$ medium) with $5 \%$ glycerol, and inorganic carbon and nitrogen sources can serve two purposes at the same time: (i) glycerol can prevent freezing of a culture thereby preventing loss of viable cells during intermittent freezing and (ii) it can support mixotrophic growth. It was observed during the experiments that a heating device is indispensable for out-door cultivation during early spring. A controlled heating of cultures during the period when the temperature drops below $0^{\circ} \mathrm{C}$ can prevent the loss of cells due to lysis during freezing and therefore supports a better yield of biomass.

(b) the amount of received light energy per day was up to 10 times higher in the out-door cultivation than in the in-door experiment. The observed irradiance values were high enough to cause photoinhibition, however the micro-algal suspension was exposed to such high PAR for a relatively short time.
Moreover, suspension mixing can provide additional protection against excessive PAR (Oliver et al., 2003). Continuous monitoring of photosynthetic performance using variable chlorophyll fluorescence instrumentation will provide additional information on light utilization as has been proposed by Torzillo et al. (1996), Torzillo et al. (1998), and Torzillo et al. (2003) for mass cultivation control.

(c) $\mathrm{CO}_{2}$ supply could be affected by the air-liquid interface area, which was larger in the out-door experiment. The larger area provided increased input of $\mathrm{CO}_{2}$ and, together with higher temperature and irradiance, led to higher growth rates.

Since there were no dataloggers inside the out-door cultivation unit, meteorological data serve as a good proxy for microclimate conditions. Mathematic models based on meteorological data and cultivation unit properties are proposed to be used for prediction of microclimate conditions in mass cultivation. Thus, short-term weather forecasts should be used for mass cultivation planning and operation.

We have proposed to use $5 \%$ glycerol in out-door mass cultivation of polar strain of Chlorella mirabilis in conditions where temperature fluctuates widely (up to $-15^{\circ} \mathrm{C}$ ). In dark or low light conditions, glycerol can support mixotrophy in micro-algal cultivation (Faust and Gantt, 1973), however glycerol utilization by Chlorella-like species strains seems to be strain- or species-specific. No glycerol utilization was reported for Chlorella vulgaris (Liang et al., 2009). The inhibitory effect of glycerol in concentrations above $1 \%(\mathrm{v} / \mathrm{v})$ was observed for this strain. However, in Chlorella protothekoides mass cultivation, glycerol addition has been used for stimulation of fatty acid production (O'Grady and Morgan, 2011). Species- and/or strain-specific reactions also influence the response to glycerol treatment, as was observed in other algal toxicity assays using different algal strains (Blanck et al., 1984; Lukavský et al., 2003). Generally, a negative or positive glycerol effect on growth rate could be influenced by environmental conditions, especially light as seen in other bioassays (Mayasich et al., 1987; Mayer et al., 1998; Cleuvers et al., 2002). Even a relatively small change in light conditions can lead to a different response.

Increased production of unsaturated fatty acids is a general response to low-temperature conditions (Satoh et al., 1979; 
Gombos et al., 1992; Hu et al., 2008; Rezanka et al., 2008, 2009). The increase was indeed observed in the in-door experiment for linoleic and elaidic acids. In the out-door experiment, the expected increase in unsaturated fatty acids content was not observed, with the exception of elaidic acid. These data indicate that the temperature conditions were not limiting for the used strains and specific adjustments of membrane fatty acids composition was not necessary for survival. In the in-door experiment, glycerol stimulated production of linoleic acid only. Such increased production of fatty acids stimulated by glycerol was observed in micro-algae (Wood et al., 1999), but have not been reported for Chlorella strains yet. The effect of glycerol addition was probably caused by different cultivation conditions as mentioned above.

\section{CONCLUSIONS}

The study showed that the biomass yield of polar soil micro-algae in mass-culture units under natural conditions of temperate/polar regions can be significantly improved by appropriate manipulation of the growth medium.

\section{REFERENCES}

Bennemann, J. R., Tillett, D. M., and Weissman, J. C. (1987). Microalgae biotechnology. Trends Biotechnol. 5, 47-53.

Blanck, H., Wallin, G., and Wängberg, S. A. (1984). Species-dependent variation in algal sensitivity to chemical compounds. Ecotoxicol. Environ. Saf. 8, 339-351.

Borowitzka, M. (1997). Microalgae for aquaculture: opportunities and constraints. J. Appl. Phycol. 9, 393-401.

Borowitzka, M. A. (2005). "Culturing microalgae in outdoor ponds," in Algal Culturing Techniques, ed. R. A. Andersen (Amsterdam: Elsevier Academic Press), 205-218.

Cerón Garcí, M. C., Fernández Sevilla, J. M., Acién Fernández, F. G., Molina Grima, E., and García Camacho, F. (2000). Mixotrophic growth of Phaeodactylum tricornutum on glycerol: growth rate and fatty acid profile. J. Appl. Phycol. 12, 239-248.

Chen, F., and Zhang, Y. (1997). High cell density mixotrophic culture of Spirulina platensis on glucose for phycocyanin production using a fedbatch system. Enzyme Microb. Tech. 20, 221-224.

Cleuvers, M., Attenburger, R., and Ratte, H. T. (2002). Combination effects of light and toxicity in algal tests. J. Environ. Qual. 31, 539-547.

Cohen, Z., Vonshak, A., and Richmond, A. (1988). Effect of environmental conditions on fatty acid composition of the red alga Porphyridium purpureum: correlation to growth rate. J. Phycol. 24, 328-332.

Davey, M. C., and Rothery, P. (1992). Factors causing the limitation of growth of terrestrial algae in maritime Antarctica during late summer. Polar Biol. 12, 595-601.

Day, J., and Tsavalos, A. (1996). An investigation of the heterotrophic culture of the green alga Tetraselmis. J. Appl. Phycol. 8, 73-77.

Dickson, L. G. (2000). Constraints to nitrogen fixation by cryptogamic crusts in a polar desert ecosystem, Devon Island, N.W.T., Canada. Arct. Antarct. Alp. Res. 32, 40-45.

Dunstan, G. A., Volkman, J. K., Barrett, S. M., Leroi, J. M., and Jeffrey, S. W. (1994). Essential polyunsaturated fatty acids from fourteen species of diatom (Bacillariophyceae). Phytochemistry 31, 155-161.

Elster, J. (1996). Algal diversity, seasonality and abundance in, and along glacial stream in Sverdrup Pass, $79^{\circ} \mathrm{N}$, Central Ellesmere Island, Canada. Memoir. Natl. Inst. Polar Res. 51, 99-118.

Elster, J. (2002). "Ecological classification of terrestrial algal communities in polar environments," in Geoecology of Antarctic Ice-Free Coastal Landscapes, eds L. Beyer and M. Bötler (Berlin: Springer-Verlag), 303-326.

Elster, J., and Benson, E. E. (2004). “Life in the polar terrestrial environment with a focus on algae and cyanobacteria," in Life in the Frozen State, eds B. J. Fuller, N. Lane, and E. E. Benson (Boca Raton: CRC Press), 111-150.

Elster, J., and Komárek, O. (2003). Ecology of periphyton in a meltwater stream ecosystem in the maritime Antarctica. Antarct. Sci. 15, 189-201.

Elster, J., Lukavský, J., Harding, K., Benson, E. E., and Day, J. G. (2008). Deployment of the encapsulation/dehydration protocol to

The used micro-algal strain Chlorella mirabilis Lukešová 10/1997 could be a valuable source of linoleic acid, since increased production was detected in glycerol treatments in both the in-door and out-door mass cultivations. Therefore, this should be considered as a perspective strain for linoleic acid production in low-temperature biotechnologies.

\section{ACKNOWLEDGMENTS}

The work was supported by the Overseas Associate Program of the Department of Biotechnology, Govt. of India (Ref: BT/IN/BTOA/26/2003), Ministry of Education, Youth and Sports of the Czech Republic projects ME 934 and LM2010009, the long-term research development project no. RVO 67985939 and project CzechGlobe - Centre for Global Climate Change Impacts Studies, Reg.No. CZ.1.05/1.1.00/02.0073. We would like to thank Mrs. Jana Šnokhousová for essential help in the preparation and operation of the experiments. Keith Edwards corrected the English.

cryopreserve polar microalgae held at the Czech Republic Academy of Science Institute of Botany. Cryo Letters 29, 27-28.

Elster, J., and Svoboda, J. (1995). "In situ simulation and manipulation of a glacial stream ecosystem in the Canadian High Arctic," in Ecosystem Manipulation Experiments: Scientific Approaches, Experimental Design and Relevant Results, eds D. Jenkins, R. C. Ferrier, and C. Kirby (Brussels: Commission of the European Communities, Institute of Hydrology, UK and Environment Canada), 254-263.

Elster, J., Svoboda, J., and Kanda, H. (2001). "Controlled environmental platform used in temperature manipulation study of a stream periphyton in the Ny-Ålesund, Svalbard," in Algae and Extreme Environments, eds J. Elster, J. Seckbach, W. F. Vincent, and O. Lhotský (Stuttgart: Cramer), 63-75.

Faust, M. A., and Gantt, E. (1973). Effect of light intensity on glycerol on the growth, pigment composition, and ultrastructure of Chroomonas sp. J. Phycol. 9, 489-495.

Gombos, Z., Wada, H., and Murata, N. (1992). Unsaturation of fatty acids in membrane lipids enhances tolerance of the cyanobycterium Synechocystis PCC6803 to low-temperature photoinhibition. Proc. Natl. Acad. Sci. U.S.A. 89, 9959-9963.

Harel, M., Koven, W., Lein, I., Bar, Y., Behrens, P., Stubblefield, J., et al. (2002). Advanced DHA, EPA and ArA enrichment materials for marine aquaculture using single cell heterotrophs. Aquaculture 213, 347-362.
Henry, G. H. R., and Svoboda, J. (1986). Dinitrogen fixation (acetylene reduction) in high arctic sedge meadow communities. Arct. Antarct. Alp. Res. 18, 181-187.

Hu, H. H., Ll, H. Y., and Xu, X. D. (2008). Alternative cold response modes in Chlorella (Chlorophyta, Trebouxiophyceae) from Antarctica. Phycologia 47, 28-34.

Kaštovská, K., Elster, J., Stibal, M., and Šantrucková, H. (2005). Microbial assemblages in soil microbial succession after glacial retreat in Svalbard (High Arctic). Microb. Ecol. 50, 396-407.

Kvíderová, J. (2010). Rapid algal toxicity assay using variable chlorophyll fluorescence for Chlorella kesslerii (Chlorophyta). Environ. Toxicol. 25, 554-563.

Kvíderová, J., and Lukavský, J. (2001). "A new unit for crossed gradients of temperature and light," in Algae and Extreme Environments, eds J. Elster, J. Seckbach, W. F. Vincent, and O. Lhotský (Stuttgart: Cramer), 541-550.

Kvíderová, J., and Lukavský, J. (2003). The cultivation of Phaeodactylum tricornutum in crossed gradeints of temperature and light. Arch. Hydrobiol. Suppl. 149/Algol. Stud. 110, 67-80.

Kvíderová, J., and Lukavský, J. (2005). The comparison of ecological characteristics of Stichococcus (Chlorophyta) strains isolated from polar and temperate regions. Arch. Hydrobiol. Suppl. 160/Algol. Stud. 118, 127-140.

Langden, C., and Onal, E. (1999). Replacement of living microalgae with spray-dried diets for 
marine mussel Mytilus galloprouicialis. Aquaculture 180, 283-294.

Lee, Y.-K., and Low, C.-S. (1992). Productivity of outdoor algal cultures in enclosed tubular photobioreactor. Biotechnol. Bioeng. 40, 1119-1122.

Liang, Y., Sarkany, N., and Cui, Y. (2009). Biomass and lipid productivities of Chlorella vulgaris under autotrophic, heterotrophic and mixotrophic growth conditions. Biotechnol. Lett. 31, 1043-1049.

Liengen, T., and Olsen, R. A. (1997). Nitrogen fixation by free-living cyanobacteria from different coastal sites in a High Arctic tundra, Spitzbergen. Arct. Antarct. Alp. Res. 29, 470-477.

Lukavský, J., Furnadjieva, S., and Cepák, V. (2003). Toxicity of metals, $\mathrm{Al}, \mathrm{Cd}$, $\mathrm{Co}, \mathrm{Cr}, \mathrm{Cu}, \mathrm{Fen}, \mathrm{Ni}, \mathrm{Pb}$, and $\mathrm{Zn}$ on microalgae, using microplate bioassay 1: Chlorella kessleri, Scenedesmus quadricauda, Sc. subspicatus and Raphidocelis subcapitata (Selenastrum capricornutum). Arch. Hydrobiol. Suppl. 149/Algol. Stud. 110, 127-141.

Masojídek, J., Torzillo, G., Kobližek, M., Kopecký, J., Bernardini, P., Sacchi, A., et al. (1999). Photoadaptation of two members of the Chlorophyta (Scenedesmus and Chlorella) in laboratory and outdoor cultures: changes in chlorophyll fluorescence quenching and the xanthophyll cycle. Planta 209, 126-135.

Mayasich, J. M., Karlander, E. P., and Terlizzi, D. E. (1987). Growth responses of Nannochloris oculata droop and Phaeodactylum tricornutum Bohlin to the herbicide atrazine as influenced by light intensity and temperature in unialgal and bialgal assemblage. Aquat. Toxicol. 10, 187-197.

Mayer, P., Frickmann, J., Christensen, E. R., and Nyholm, N. (1998). Influence of growth conditions on the results obtained in algal toxicity assays. Environ. Toxicol. Chem. 17, 1091-1098.

O'Grady, J., and Morgan, J. A. (2011). Heterotrophic growth and lipid production of Chlorella protothecoides on glycerol. Bioprocess Biosyst. Eng. $34,121-125$.

Oliver, R. L., Whittington, J., Lorenz, Z., and Webster, I. T. (2003). The influence of vertical mixing on the photoinhibition of variable chlorophyll a fluorescence and its inclusion in a model of phytoplankton photosynthesis. J. Plankton Res. 25, 1107-1129.

Pandey, K. D., Shukla, S. P., Shukla, N. P., Giri, D. D., Singh, J. S., Singh, P., et al. (2004). Cyanobacteria in Antarctica: ecology, physiology and cold adaptation. Cell. Mol. Biol. 50, 575-584.

Řezanka, T., Nedbalová, L., Elster, J., Cajthaml, T., and Sigler, K. (2009). Very-long-chain iso and anteiso branched fatty acids in $\mathrm{N}$-acylphosphatidylethanolamines from a natural cyanobacterial mat of Calothrix sp. Phytochemistry 70, 655-663.

Řezanka, T., Nedbalová, L., and Sigler, K. (2008). Unusual medium chain-chain polyunsaturated fatty acids from snow alga Chloromonas brevispina. Microbiol. Res. 163, 373-379.

Samejima, H., and Myers, J. (1958). On the heterotrophic growth of Chlorella pyrenoidosa. J. Gen. Microbiol. 18, 107-117.

Sanchez, S., Martinez, M. E., Molina, E., and Casa, J. A. (1995). Skeletonema costatum, as a potential source of fatty acids and single cell protein $(\mathrm{SCP})$ : the effect of $\mathrm{pH}$ on growth rate and biomass composition. J. Mar. Biotechnol. 2, 23-26.

Satoh, N., Murata, N., Miura, Y., and Ueta, N. (1979). Effect of growth temperature on lipid and fatty acid composition in the blue-green algae, Anabaena variabilis and Anacystis nidulans. Biochim. Biophys. Acta 572, 19-28.

Shukla, S. P., and Kashyap, A. K. (2003). An assessment of biopotential of three cyanobacterial isolates from Antarctic for carotenoid production. Indian J. Biochem. Biophys. 40, 362-366.

Shukla, S. P., Kvíderová, J., and Elster, J. (2011). Nutrient requirements of polar Chlorella-like species. Czech Polar Rep. 1, 1-10.

Shukla, S. P., Mishra, A. K., and Kashyap, A. K. (1997a). Influence of low temperature and salinity stress on growth behaviour and pigment composition of Antarctic and tropical isolates of a diazotrophic cyanobacterium Anabaena. Indian J. Exp. Biol. 35, 1224-1228.

Shukla, S. P., Padney, K. D., and Kashyap, A. K. (1997b). Nitrogen fixation, ammonium transport and glutamine synthetase activity in an Antarctic cyanobacterium Anabaena sp.: influence of temperature. J. Plant Physiol. 150, 351-354.

Staub, R. (1961). Ernahrungsphysiolo gisch-autokolagische Untersuchungenan der planktonische Blaualgae Ocillatoria rubescens DC. Schweis. Z. Hydrol. 23, 82-198.

Tan, C. K., and Johns, M. R. (1991). Fatty acid production by heterotrophic Chlorella sacharophilla. Hydrobiologia 215, 13-19.

Thimijan, R. W., and Heins, R. D. (1983). Photometric, radiometric and quantum light units of measure: a review of procedures for interconversion. HortScience 18, 818-822.

Torzillo, G., Accolla, P., Pinzani, E., and Masojidek, J. (1996). In situ monitoring of chlorophyll fluorescence to assess the synergistic effect of low temperature and high irradiance stresses in Spirulina cultures grown outdoors in photobioreactors. J. Appl. Phycol. 8, 283-291.

Torzillo, G., Bernardini, P., and Masojídek, J. (1998). On-line monitoring of chlorophyll fluorescence to assess the extent of photoinhibition of photosynthesis induced by high oxygen concentration and low temperature and its effect on the productivity of outdoor cultures of Spirulina platensis (Cyanobacteria). J. Phycol. 34, 504-510.

Torzillo, G., Goksan, T., Faraloni, C., Kopecký, J., and Masojídek, J. (2003). Interplay between photochemical activities and pigment composition in an outdoor culture of Heterococcus pluvialis during shift from the green to red stage. J. Appl. Phycol. 15, 127-136.
Vonshak, A., and Torzillo, G. (2004). "Environmental stress physiology," in Handbook of Microbial Culture, Biotechnology and Applied Phycology, ed. A. Richmond (Oxford: Blackwell Science), 57-82.

Walker, J. K. M., Egger, K. N., and Henry, G. H. R. (2008). Longterm experimental warming alters nitrogen-cycling communities but site factors remain the primary drivers of community structure in high arctic tundra soil. ISME J. 2, 982-995.

Wood, B. J. B., Grimson, P. H. K., German, J. B., and Turner, M. (1999). "Photoheterotrophy in the production of phytoplankton organisms," in Progress in Industrial Microbiology, eds R. Osinga, J. Tramper, T. G. Burgess, and R. H. Wijffels (Amsterodam: Elsevier), 175-183.

Zhou, B., Liu, W., Qu, W., and Tseng, C. K. (1991). Application of Spirulina mixed feed in the breeding of bay scallop. Bioresour. Technol. 38, 229-232.

Conflict of Interest Statement: The authors declare that the research was conducted in the absence of any commercial or financial relationships that could be construed as a potential conflict of interest.

Received: 30 August 2012; accepted: 05 April 2013; published online: 23 April 2013.

Citation: Shukla SP, Kvíderová J, Tř́iska $J$ and Elster J (2013) Chlorella mirabilis as a potential species for biomass production in low-temperature environment. Front. Microbiol. 4:97. doi: 10.3389/fmicb.2013.00097

This article was submitted to Frontiers in Extreme Microbiology, a specialty of Frontiers in Microbiology.

Copyright @ 2013 Shukla, Kvíderová, Tríska and Elster. This is an openaccess article distributed under the terms of the Creative Commons Attribution License, which permits use, distribution and reproduction in other forums, provided the original authors and source are credited and subject to any copyright notices concerning any third-party graphics etc. 